\title{
Barriers to Exportation: Sri Lankan Garment Exportation Industry
}

\author{
Y. Samodha Dharmasiri \\ University of Melbourne, Melbourne, Australia \\ R. Gayathri Ranasinghe \\ UNSW, Canberra, Australia
}

\begin{abstract}
Over the years, Sri Lankan apparel export industry has proven as one of the most significant contributors to nation's economy. However, despite of the significant development throughout all these years, it has faced many problems. They are introduced as barriers within the environment of industrial work floor and barriers within the regulatory agencies. Research was conducted based on the barriers within regulatory agencies. Concept was analyzed to promote profitable expansion to garment industries in Sri Lanka. Project identified ways to solve selected issues such as achieving quality requirements, goods examination at customs, VAT (Value Added Tax) registration renewal, document declaration problems, and space-booking problems when shipping which are encountered at the point of exportation. Based on key findings, web-based business solution (www.samodha.com) was proposed which acts as a virtual expert performing tasks previously done manually, starting from quality testing until the shipment. Observing the evaluation regarding applicability toward resolving the problem, it is evident that respondents were satisfied with system functionalities provided to support the business requirements. Proposed solution has the capacity to increase efficiency and effectiveness of apparel exportation of Sri Lanka. Furthermore, this solution can be extended to other industries with certain customization to establish economic growth and sustainability of Sri Lanka.
\end{abstract}

Keywords: apparel industry, exportation barriers, goods declaration, space booking, VAT (Value Added Tax) and quality authorization

Trading globally enhances the domestic competitiveness and extends the sales potential of existing products that in turn results in an increase in profits to participating countries (Daily FT, 2015). Over the years, Sri Lankan apparel export industry has proven as one of the most significant and dynamic contributors for the nation's economy. As per Kelegama and Epaarachchi (2002), it has a well-known reputation for exporting readymade wear to UK market and exclusive manufacturing for selected UK retailers. "Apparel industry is the primary foreign exchange earner accounting to $40 \%$ of the total exports and $52 \%$ of industrial products exports" (Export Development Board, 2015).

Y. Samodha Dharmasiri, BS, Information Systems with Business Management, University of Westminster, UK, MSC, Information Systems, University of Melbourne, Australia; research fields: information systems, business management.

Corresponding author: R. Gayathri Ranasinghe, BS, Information Systems, Manchester Metropolitan University, UK, MBA, University of Sri Jayewardenepura, Sri Lanka, Ph.D. candidate, UNSW, Canberra, Australia; research fields: entrepreneurship, business management, database systems, information systems, software quality. 
Although exportation of garments plays a major role to the development of Sri Lankan economy, barriers to exporting of garments continue to exist with no proper solutions. On their way to development, it has faced many problems, including those related to the work practices, operational surroundings, trading environment, and the state of affairs in trading (Kelegama, 2009). Lower productivity and poor manufacturing processes remain a weakness in this industry affecting competition with the other producers.

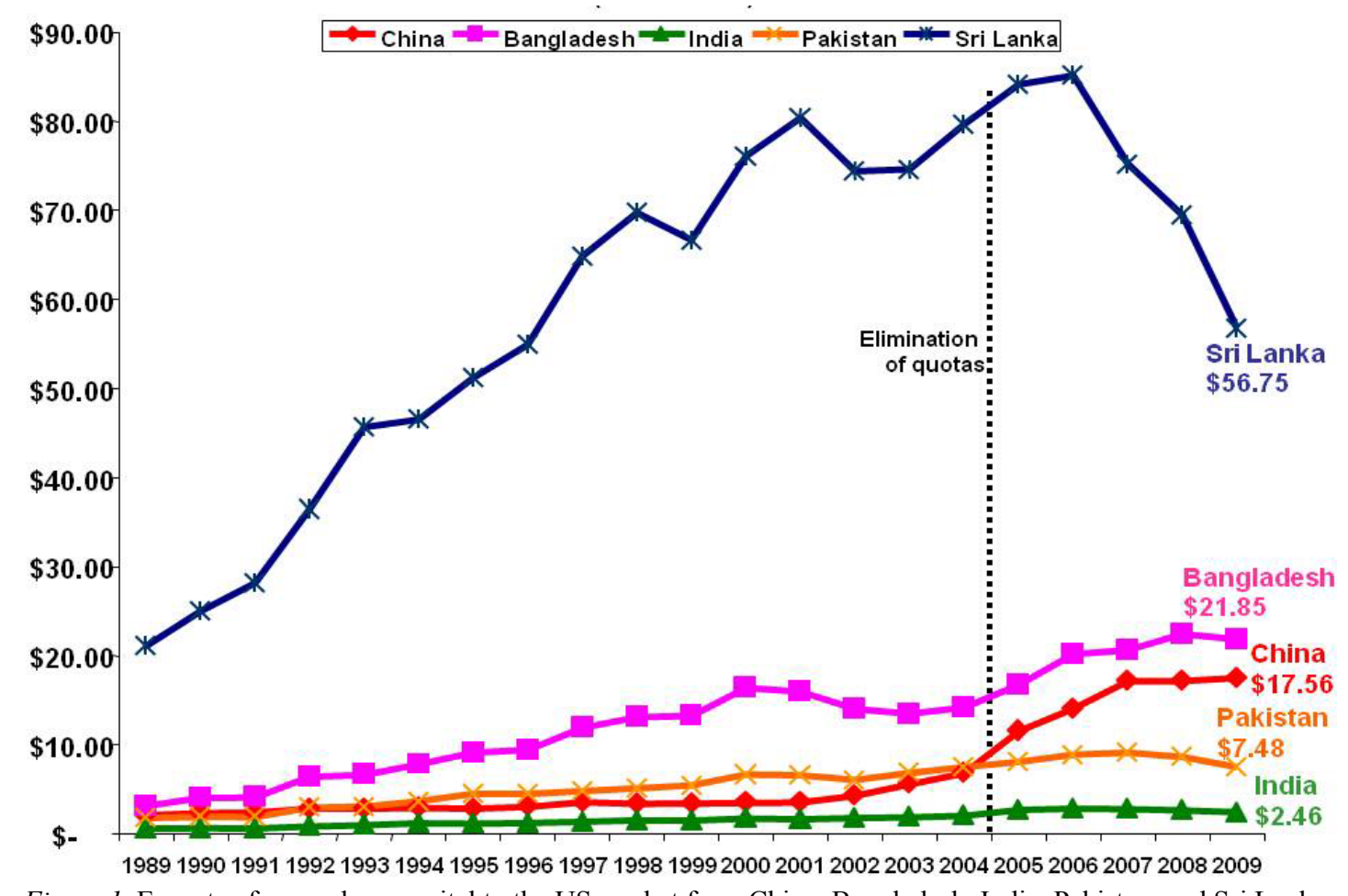

Figure 1. Exports of apparel per capital to the US market from China, Bangladesh, India, Pakistan, and Sri Lanka.

According to the above illustration in Figure 1 obtained from Central Intelligence Agency (2014), it can be noted that Sri Lanka has done a significant contribution in terms of exporting garments to USA when compared with other countries, however since the mid of year 2004 this contribution has started to decrease while other countries' exportation has continued to increase. This has led to decrease in profit obtained from Sri Lankan exports of apparel. Therefore, it is vital to research about the challenges faced by apparel industry exporters in order to up lift the exportation of garments from Sri Lanka.

\section{Problem Domain}

Category 1 - Barriers within the environment of industrial work floor:

Commitment demonstrated by the apparel workers is at an unsatisfactory level. Most enterprises' low investment in the technology has created a noticeable disadvantage to gain competitive advantage in the industry. Minor mishaps such as poor "on time delivery" practices and last minute rush for export shipments have created major issues in the long term.

Category 2-Barriers within the environment of regulatory agencies:

These are operations beyond the control of buyer and manufacturer. These types of factors are rarely being analyzed earlier and are vital to research about it to fulfill the expectations for a successful trade. 
(1) Quality and licensing requirement;

Often exporting firms do not have requisite documents to prove conformity with the rules of origin and domestic content.

(2) Goods examination at customs;

There is no transparency in the inspection procedures of exports shipments.

(3) Customs VAT (Value Added Tax) registration;

All importers/exporters need Customs House $(\mathrm{CH})$ registration, which needs to renew annually where expiry will terminate the exportation facility. This is double over functioning task that has already been done at Tax Office that needs additional resources. Though the authorities are able to share the details and agreement, exporters are compelled to do double task.

(4) Customs Declaration (CusDecs) problems;

Barriers at ports include excessive paperwork requirements, lack of standardized documents, theft and pilferage as well.

(5) Space bookings for airline and shipping lines.

Common problem with space bookings for airline and shipping lines is overselling or overbooking. Exporters miss the space or do not show up due to rebookings afterwards.

\section{Literature Review}

\section{Barriers Within the Environment of Regulatory Agencies}

Quality and authorizing requirements. As reported by Pararajasingham (2007), even though local textile industry was protected during the closed economic periods, with the start of open economy, the industry enterprises failed to meet the garment industry requirements needed for an export market. According to Pararajasingham, with the current economy, apparel exporters have been unsuccessful meeting the quality requirements of garments for exportation. Accordingly, quality standards are uplifted automatically leading to authorizing requirements.

Goods clearance at customs. There are two types of time-consuming examination/testing procedures that process at the point of exports:

(1) Quantitative examination to verify whether the intended quantity is shipped;

(2) Verification of the actuality of raw materials, consumption of raw materials, and ascertaining the genuine wastage. This verification takes place prior to the authorization of the export at the verification yards. This proceeds in three stages: (a) examination by panel of officers; (b) examination in detail; (c) test check or random check.

There is no transparency in the inspection procedures of exports shipments, and lack of clarity on documentation required in small ports that increases waiting time of exports. According to the article in Accenture (2014), customs processes that create delays with mild improvements in security create problematic environment for the traders to do business with a country. The conclusion of the fact is reduction in time taken to transport cargo from production to shipping can uplift the growth in exports. A research conducted by Sundar (2001), regarding Indian apparel exports reveals common problems faced by apparel exporters, at the point of exportation, including import restraints, high customs duties, additional taxes, and burdensome clearance formalities. South Asia is characterized by inefficient regulatory (e.g.: customs) procedures, which often increase clearance time. Customs procedures must be simplified and fully computerized as this will 
enhance transparency in the system and address high levels of corruption (Khorana \& Soo, 2010).

Customs VAT registration. This is a repeated work, which is already done by exporters at the Inland Revenue Department. Though the authorities are able to share the details and agreement, exporters are compelled to do double task. All importers/exporters need Customs House $(\mathrm{CH})$ registration, which needs to renew annually where expiry will terminate the exportation facility. Wijayasiri and Jayaratne (2009) put forward a detailed fact on why this could be a barrier for the exporters. They mention for an entity to provide services of a Customs House Agent (CHA), it is necessary that the service provider has a CHA license. In order to obtain a license, the company needs to satisfy the requirements by passing the CHA exam held by the customs.

According to the Association of Clearing and Forwarding Agents (ALFA), the demand to sit for this exam far exceeds the supply since only a limited number of persons are allowed to follow the course. The CHA license is valid for a period of one year, after which it has to be renewed. Therefore, as Wijayasiri and Jayaratne (2009) declared, the degree of obtaining $\mathrm{CH}$ registration is essential; however, acquiring it is a complex process.

Customs Declaration problems. This is a major problem that most apparel exporters experience regarding document clearance at customs. Sundar (2001) pointed out that according to the trade sources in India, their country customs procedures are too complex and time consuming. She further states that there are frequent delays in documentation clearance. The above statement made by Sundar is proven by the following chart created using data obtained from Sri Lanka Customs. The pie chart shows the percentage of number of CusDecs cleared in relation to the number of days taken for the documentary clearance of export CusDecs.

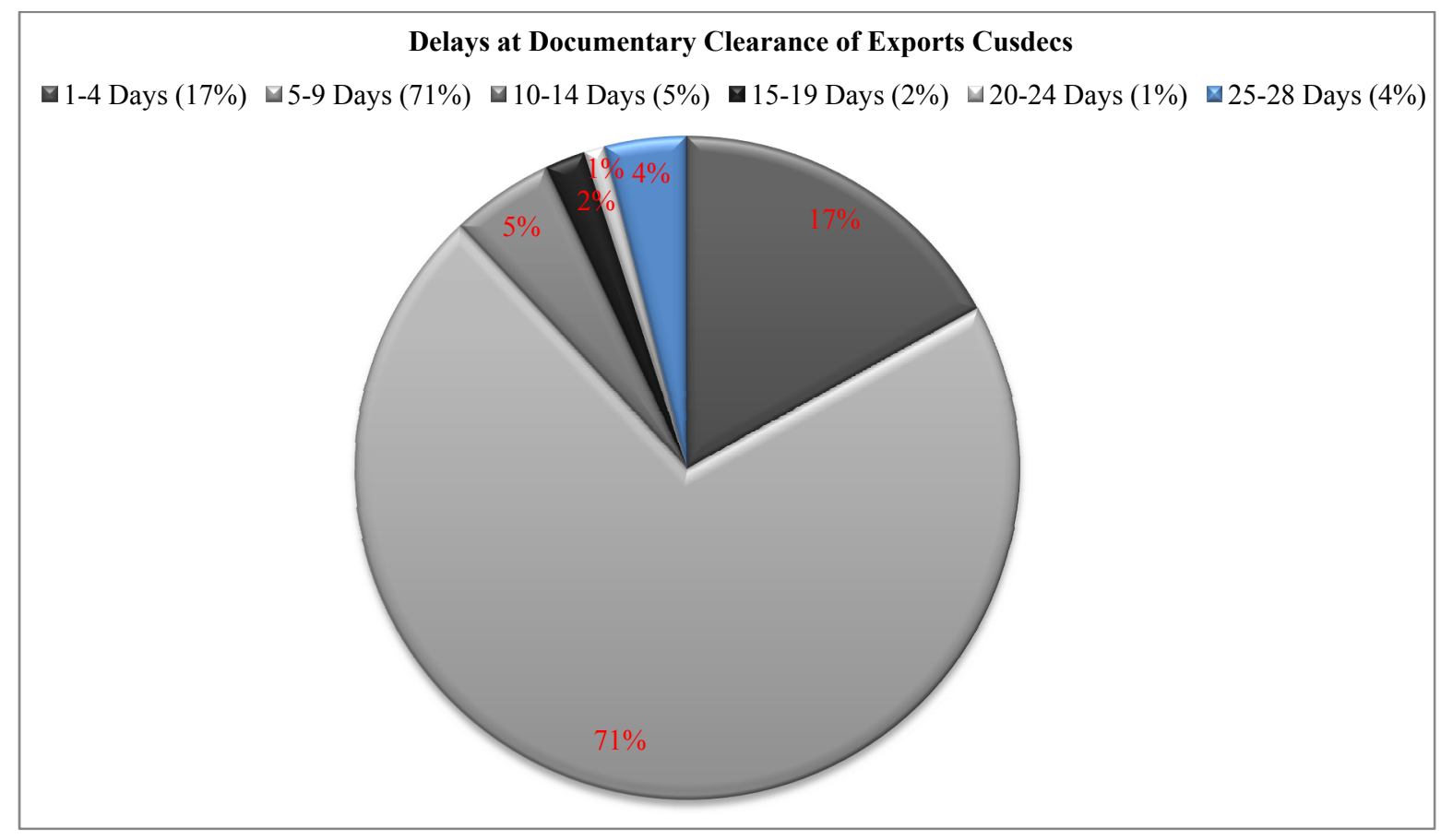

Figure 2. Delays at documentary clearance of exports CusDecs.

The chart as shown in Figure 2 is constructed for the Cusdecs cleared within each month from January 2014 to June 2014 as a total. The chart in Figure 2 proves that only 17\% of export CusDecs' documents are 
cleared on time. Most takes around 5-9 days for the clearance. In total, 83\% of CusDecs experience delays in document clearance. Delays in CusDecs document clearance directly affect the export rebate, which in returns affect the pricing. Therefore, this is a major problem that most apparel exporters experience regarding document clearance at customs.

CusDecs that processes through Board of Investment (BOI) and customs is independent. The general practice allows up to five maximum amendments before the document finalization for the export. A study conducted from data that are obtained from Sri Lanka Customs reveals most number of post entry modifications occur at Colombo BOI leading for the traders to experience considerable delays with document clearance (Board of Investment, 2000).

Space bookings for airline and shipping lines. Common problems with space bookings for airline and shipping lines are overselling or overbooking. Exporters miss the space or do not show up due to rebookings afterwards. Overbooking concerns with booking space more than accommodated for shipping which fills space in all of voyages. A court case that was argued in 1979 provides a relative example to the above fact. According to Open Jurist (1979), Ralph Nader filed a suit in the District Court against Allegeheny Airlines in 1972 stating he did a space booking in the airlines prior to the boarding. Unfortunately, he was not offered the seat at the end.

District Court decided that Allegheny Airlines is responsible for the disarray Ralph Nader experienced. Allegheny Airlines appealed to the Supreme Court regarding the case. The appellant Allegheny Airlines, stated and proved at the appeal, that overbooking/overselling is a general practice when space booking in airlines that otherwise the airline would be at a loss. The usual practice should be even though a booking is confirmed a payment should be done for the passenger to secure the space. Accessing the suit filed by Ralph Nader against Allegheny Airlines, Supreme Court made the final judgment that overbooking is a common industry practice in airlines, designed to ensure that each flight leaves with as few empty seats as possible despite the large number of "no-shows" reservation-holding passengers who do not appear at flight time.

Conclusion that can be extracted from the above incident reported on United States Court of Appeals in 1980 is that overbooking for airline and shipping lines is inevitable and therefore the traders have to be adjusted to this barrier by doing the necessary payments on time even though a booking confirmation is done.

\section{Methodology}

\section{Research Approach}

The inductive approach was selected since it provided a chance to observe the problem at the first stage of the research. Barriers that Sri Lankan apparel exporters faced during exportation to overseas were the identified problems and through analysis of various literatures on the subject matter, it was identified that there were several factors which were having an impact on Sri-Lankan apparel exportation. There variables were used to develop hypothesis on the relationship within the dependent variables (barriers) and a pattern was developed in order to formulate a theory through analysis of quantitative data validated by qualitative assessments (questionnaires and interviews).

\section{Fact Finding Techniques}

Table 1 below shows the chosen fact finding techniques for the research. 
Table 1

Fact Finding Selection and Justification

\begin{tabular}{|l|l|}
\hline Selected technique & Justification \\
\hline $\begin{array}{l}\text { Literature review and survey } \\
\text { (document sampling) }\end{array}$ & $\begin{array}{l}\text { Literature review containing summaries and arguments about barriers that apparel exporters } \\
\text { encounter during exportation procedures would provide a solid background to confirm the } \\
\text { problem domain. By having a sound understanding of each area, the limitations and existing gaps } \\
\text { can be identified for the proposed solution. }\end{array}$ \\
\hline Questionnaires & $\begin{array}{l}\text { Information can be gathered from a higher number of exporters who are located in several areas } \\
\text { of the country. This process may not bring in as many responses as preferred, but this process is } \\
\text { cost effective and can be done in short period of time. }\end{array}$ \\
\hline Interviews & $\begin{array}{l}\text { Technique is used as a data validation technique to validate the accuracy of the responses that } \\
\text { were gathered through the questionnaires. }\end{array}$ \\
\hline
\end{tabular}

Sampling Techniques

After comparing and contrasting different probability and non-probability sampling methods mainly snowball sampling was chosen, in relation to identifying a few people in every sector that is relevant to the research.

Table 2 below shows the chosen sampling techniques for the research.

Table 2

Different Sampling Methods to Each Specified Task

\begin{tabular}{|c|c|c|c|}
\hline Requirement & $\begin{array}{l}\text { Fact-finding } \\
\text { method }\end{array}$ & $\begin{array}{l}\text { Sampling } \\
\text { method }\end{array}$ & Justification \\
\hline $\begin{array}{l}\text { Identify factors affecting } \\
\text { apparel exportation within the } \\
\text { regulatory agencies. }\end{array}$ & $\begin{array}{l}\text { Document } \\
\text { sampling }\end{array}$ & $\begin{array}{l}\text { Not } \\
\text { applicable }\end{array}$ & $\begin{array}{l}\text { Various different literature views were available and the data } \\
\text { were gathered and applied to the current context. Relatively less } \\
\text { time consuming and being able to study the areas thoroughly } \\
\text { taking in different perspectives from different literature. }\end{array}$ \\
\hline $\begin{array}{l}\text { Validate and confirmation of } \\
\text { the factors and its } \\
\text { applicability to the Sri Lankan } \\
\text { context. Identify sub barriers } \\
\text { affecting each main barrier. } \\
\end{array}$ & $\begin{array}{l}\text { Initial interviews } \\
\text { with the industry } \\
\text { personnel }\end{array}$ & $\begin{array}{l}\text { Snowball } \\
\text { sampling }\end{array}$ & $\begin{array}{l}\text { Presented the identified factors and got the views and opinions } \\
\text { of industry experts on the applicability of these factors. } \\
\text { Qualitative data were required since they are applied to a } \\
\text { specific context. Snowball sampling was used so that key } \\
\text { industry personnel can be identified. }\end{array}$ \\
\hline $\begin{array}{l}\text { Test the gathered variables } \\
\text { and sub factors as to their } \\
\text { effect on exportation. }\end{array}$ & Questionnaire & $\begin{array}{l}\text { Stratified } \\
\text { random } \\
\text { sampling }\end{array}$ & $\begin{array}{l}\text { A questionnaire was distributed since statistical data were } \\
\text { targeted through this process and it required high amount of } \\
\text { data. Exporters who are engaged in the business since one year } \\
\text { to around } 10 \text { years were identified as the most prominent } \\
\text { segment in the industry and the group was defined as the strata, } \\
\text { out of which random sampling was conducted. }\end{array}$ \\
\hline $\begin{array}{l}\text { Identify specific factors } \\
\text { affecting the employees. }\end{array}$ & $\begin{array}{l}\text { Focused group } \\
\text { discussions }\end{array}$ & $\begin{array}{l}\text { Multi stage } \\
\text { cluster } \\
\text { sampling }\end{array}$ & $\begin{array}{l}\text { Focus group discussion together with personal chats was used to } \\
\text { obtain detailed qualitative information from the employees as to } \\
\text { any specific experience they have dealt with. Different clusters } \\
\text { were defined within the specified group mentioned above and } \\
\text { selective sample was generated containing people from each } \\
\text { group based on their role in the company. }\end{array}$ \\
\hline Analyze the requirements. & $\begin{array}{l}\text { Interviews with } \\
\text { industry experts }\end{array}$ & $\begin{array}{l}\text { Snowball } \\
\text { sampling }\end{array}$ & $\begin{array}{l}\text { Requirements derived through questionnaires and focus group } \\
\text { discussions were discussed with industry personnel so that } \\
\text { qualitative validation can be performed. }\end{array}$ \\
\hline $\begin{array}{l}\text { Validate the requirement } \\
\text { capturing. }\end{array}$ & Prototyping & $\begin{array}{l}\text { Snowball } \\
\text { sampling }\end{array}$ & $\begin{array}{l}\text { User (Exporter) evaluation will be used to assess the level for } \\
\text { capturing requirements. }\end{array}$ \\
\hline
\end{tabular}

\section{Data Analysis}

Figure 3 below shows the independent variables connected to the dependent variable (apparel exportation). 


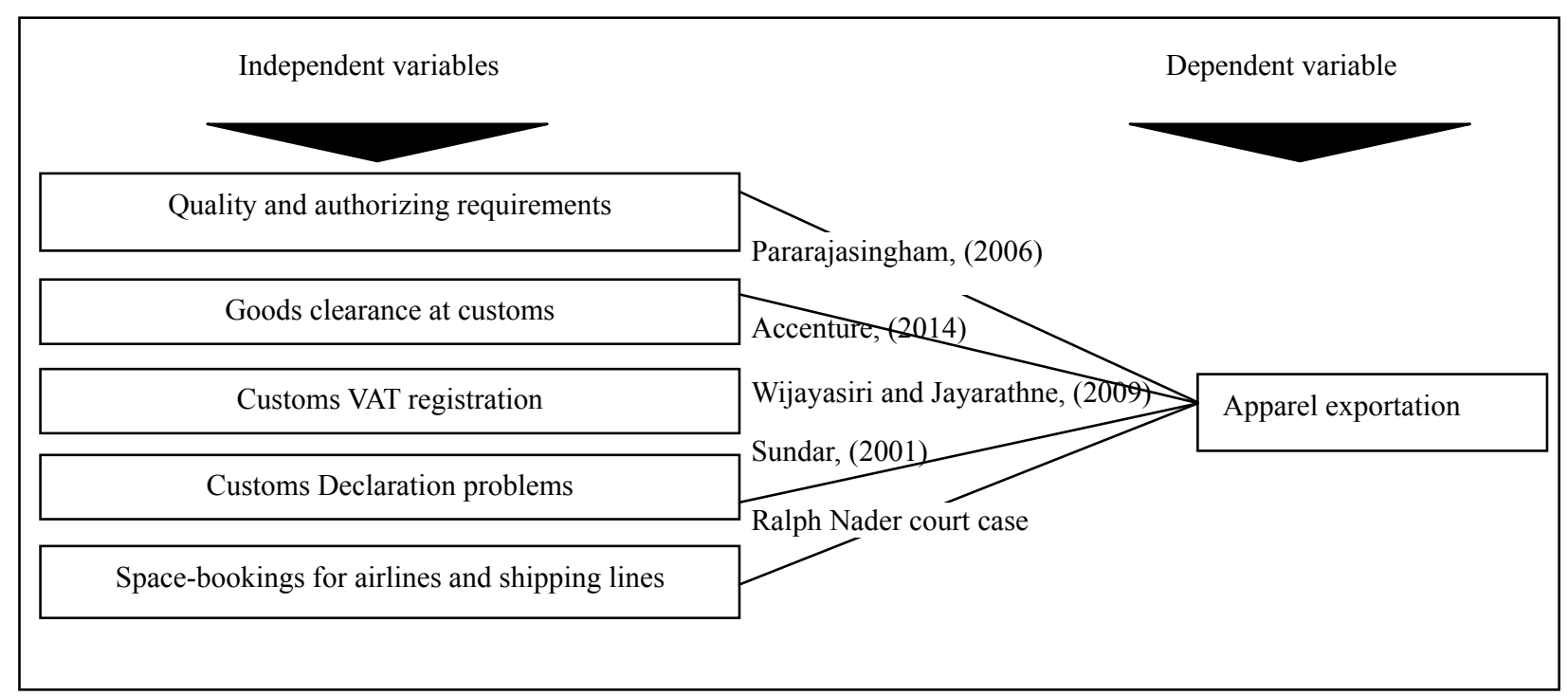

Figure 3. Concept model.

\section{Hypothesis}

The hypothesis is formulated in order to judge the impact of negative or positive results based on apparel exporters while exporting goods to overseas.

$\mathrm{H}_{1}$ : Exporters who have fulfilled all quality and authorizing requirements have a significant benefit while conducting export operations.

$\mathrm{H}_{2}$ : Exporters who have adequate knowledge in the process of customs clearance that takes place at customs authorities have a significant benefit while conducting export operations.

$\mathrm{H}_{3}$ : Exporters who have obtained necessary license for VAT registration have a significant benefit while conducting export operations.

$\mathrm{H}_{4}$ : Exporters who have not been delayed at customs documentation process have a significant benefit while conducting export operations.

$\mathrm{H}_{5}$ : Exporters who have done the necessary payments on time while booking airlines/shipping lines have a significant benefit while conducting export operations.

\section{Data Analysis and Findings}

Correlation analysis. The formulated hypothesis will be proved to identify the impact on identified variables. Statistical package for social sciences (SPSS) software was used to prove the identified hypothesis.

Table 3 below shows the correlation analysis which proves to identify the impact on the identified variables.

Table 3

Correlation Analysis

\begin{tabular}{|l|l|l|l|l|l|}
\hline \multirow{2}{*}{ Dependent variable } & \multicolumn{3}{|l|}{ Independent variable } \\
\cline { 2 - 6 } & $\begin{array}{l}\text { Quality and } \\
\text { authorizing } \\
\text { requirements }\end{array}$ & $\begin{array}{l}\text { Goods clearance } \\
\text { at customs }\end{array}$ & $\begin{array}{l}\text { Customs VAT } \\
\text { registration }\end{array}$ & $\begin{array}{l}\text { Customs } \\
\text { Declaration } \\
\text { problems }\end{array}$ & $\begin{array}{l}\text { Space bookings } \\
\text { for airlines and } \\
\text { shipping lines }\end{array}$ \\
\hline $\begin{array}{l}\text { Exportation of garments in the } \\
\text { apparel industry of Sri Lanka }\end{array}$ & $0.670^{* *}$ & $0.745^{* *}$ & $0.688^{* *}$ & $0.820^{* *}$ & $0.760^{* *}$ \\
\hline
\end{tabular}

Note. ${ }^{* *}$ Correlation is significant at the 0.01 level (2-tailed). 
Proving hypothesis. The relationship between exportation of garments in the apparel industry of Sri Lanka and quality and authorizing requirements barrier has a positive value of 0.670 . Also the correlation is significant at the 0.01 level (2-tailed). Therefore, the hypothesis of fulfilling quality and authorizing requirements positively influences garment exportation of Sri Lanka.

The relationship between exportation of garments in the apparel industry of Sri Lanka and goods clearance at customs barrier has a positive value of 0.745 . Also the correlation is significant at the 0.01 level (2-tailed). Therefore, the hypothesis of goods clearance at customs positively influences garment exportation of Sri Lanka.

The relationship between exportation of garments in the apparel industry of Sri Lanka and customs VAT registration barrier has a positive value of 0.688 . Also the correlation is significant at the 0.01 level (2-tailed). Therefore, the hypothesis of customs VAT registration positively influences garment exportation of Sri Lanka.

The relationship between exportation of garments in the apparel industry of Sri Lanka and Customs Declaration problems barrier has a positive value of 0.820 . Also the correlation is significant at the 0.01 level (2-tailed). Therefore, the hypothesis of Customs Declaration problems positively influences garment exportation of Sri Lanka.

The relationship between exportation of garments in the apparel industry of Sri Lanka and space bookings for airlines and shipping lines barrier has a positive value of 0.760 . Also the correlation is significant at the 0.01 level (2-tailed). Therefore, the hypothesis of space bookings for airlines and shipping lines positively influences garment exportation of Sri Lanka.

\section{Discussions and Conclusions}

The key findings were extracted from the results obtained from the survey conducted on the exporters as a questionnaire and interviews with the stakeholders.

At present, Sri Lankan exporters per annum carry only up to 2,500 exportations with a limited range of two to five countries. The main reason for choosing the same range of countries is due to the fair amount of product price given for the exporter. Rather than a way out to achieve the standards that are required to get the goods approved at the Buying Office, a solution to coordinate exporters with the Buying Office is recommended. Regularly exporters waste time to hand over the cargo to the vessel. Exporters mainly waste time due to the delays happen at BOI and customs. Due to the verification delays that take place at examination yard, examination processes complete at a time in the vicinity of the cargo shutout time which results in not being able to hand over the consignment to the vessel. Exporters are dissatisfied with the goods handling procedures and documents clearance at customs and BOI. Majority of the exporters agree license renewal procedures are difficult to handle and 33\% respond that the overall experience is neutral. VAT registration renewal is a complete waste of time, since most of the time the data that were initially submitted will not change over time.

Most exporters experience their CusDecs being subjected to change for around 6-10 times. Thus, it proves exporters waste time waiting for the documents to get cleared and delay in document clearance will postpone the next activities. Therefore, the efficiency of both authorities is questionable. Clients recommend an external agent to watch the bookings and act accordingly. Majority of the exporters spend around Rs. 16,000 to Rs. 20,000 for cargo handling procedures. Web portal with the advance technology, run by a highly skilled staff should compensate that amount. 


\section{Recommendations and Further Work}

The solution can be expanded from Sri Lanka to global market targeting apparel exporters worldwide. The variables should be assessed regularly so that the business is in line with the environmental changes. These changes should be incorporated to the system. Similar research can be carried out for apparel importation as well. The research can be extended to address the barriers encountered by apparel exporters in the industrial work floor.

\section{Closing Remark}

Apparel industry exportation of Sri Lanka is at a declining phrase of its growth curve due to various barriers of which mainly the barriers faced regulatory agencies. The research aims to provide a solution for the main barriers they come across by creating a virtual agent carrying out the hard tasks of the exporters. The solution added a silver lining to the dark cloud of decrease in apparel industry exportation of Sri Lanka through features such as virtual agent carrying out the goods examination at customs/BOI, quality testing processes, VAT registration renewal on time, booking space for the shipment purposes, declaring documents on time without leading to post entry modifications.

Apparel exporters could get relived from the tiresome manual tasks saving massive amount of time where employees in the enterprises achieved the same benefit. By having a virtual agent acting as guide to the entrepreneurs who are engaged in this business, it is a substantial aid as they are new to the industry. Regulatory agencies and government officials are benefitted as the clients who come for their service are experts in procedures and prepared with necessary documents and goods, making their duties easy and transparent. Banks could expand their business by providing means in which exporters could carry out their payments through their banks which was a cost free promotion. Additionally, since this solution concept was brought up for the first time in Sri Lanka, this could be a possible way for future researchers to innovate similar solutions for other industries.

\section{References}

Accenture. (2014). Bordering on behind the times: The customs operating model must change-Accenture. Retrieved from $\mathrm{http}$ //www.accenture.com/us-en/Pages/insight-bordering-behind-times-customs-operating-model-must.aspx

Board of Investment. (2000). Provincial distribution of garment establishments. Retrieved from http://www.boi.lk/2009/index. asp

Central Intelligence Agency. (2014). Economy overview. Retrieved from https://www.cia.gov/library/publications/ the-world-factbook/fields/print_2116.html

Daily FT. (2015). The time has come for Sri Lanka to look beyond apparel exports. Retrieved from http://www.ft.lk/2014/03/21/the-time-has-come-for-sri-lanka-to-look-beyond apparel exports/

Kelegama, S. (2009). Ready-made garment industry in Sri Lanka: Preparing to face the global challenges. Asia-Pacific Trade and Investment Review, 39(4), 51-67.

Kelegama, S., \& Epaarachchi, R. (2002). Garment industry in Sri Lanka. In S. Kelegama and R. Epaarachchi, Garment industry in South Asia: Rags or riches? (pp. 197-240). Switzerland: International Labour Office.

Khorana, S., \& Soo, K. T. (2010). Barriers to exporting to the EU: Evidence from textiles and leather goods firms in India. Retrieved from http://www.eiit.org/WorkingPapers/Papers/FirmLevelGeneral/FREIT363.pdf

Open Jurist. (1979). Ralph Nader, Connecticut Citizen Action Group v. Allegheny Airlines, inc., appellant. Retrieved from http://openjurist.org/ 626/f2d/1031/nader-v-allegheny-airlines-inc

Sundar, S. (2001). India's textile and apparel industry. Retrieved from http://www.usitc.gov/publications/332/PUB3401.PDF

Wijayasiri, J., \& Jayaratne, S. (2009). The impact of information technology (IT) in trade facilitation on small and medium enterprises (SMEs) in Sri Lanka. Retrieved from http://www.unescap.org/sites/default/files/AWP\%20No.\%2065.pdf

Export Development Board (EDB). (2015). Apparel manufaturers, suppliers \& exporters in Sri Lanka. Retrieved from http://www.srilankabusiness.com/apparel/

Pararajasingham, E. (2007). In the beginning.... Retrieved from http://www.sundaytimes.lk/070415/FinancialTimes/ft312.html 